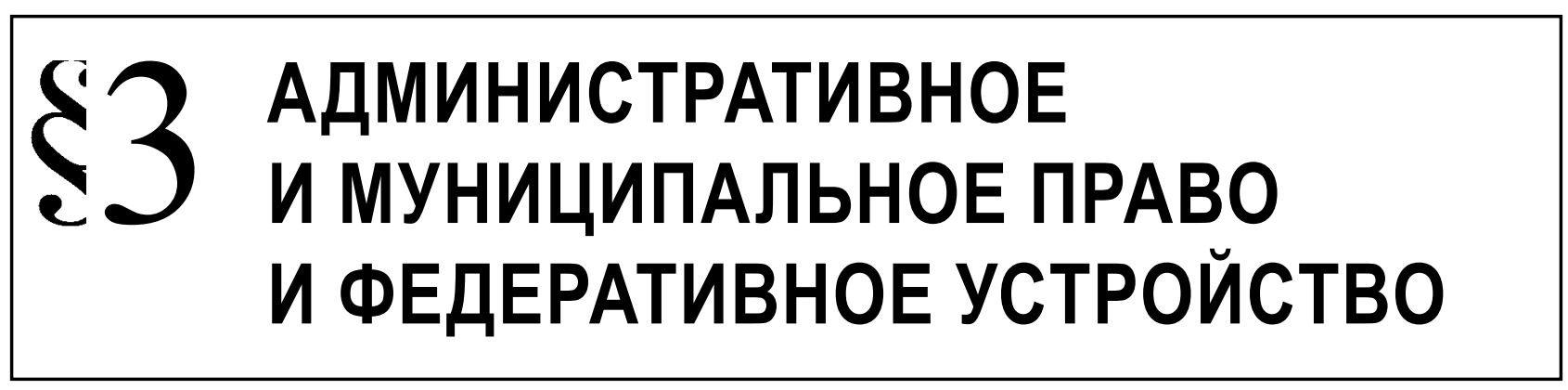

Смирнова В.В.

\title{
К ВОПРОСУ О РАЗВИТИИ ПРАВОВЫХ ОСНОВ РОССИЙСКОГО ФЕДЕРАЛИЗМА И ПРОБЛЕМЫ УПРАВЛЕНИЯ
}

\begin{abstract}
Аннотация: В статье отмечается, что управление общественно-политическими процессами и тенденциями, свойственными нашему государству на современном этапе, невозможно без выявления специфики устройства Российской Федерации. Конституция Российской Федерации, принятая в 1993 г., закрепив принцип федерализма как одну из основ конституционного строя России, подтвердила федеративный характер нашего государства. Яв-ляясь многонациональной страной с обширной территорией, различными природными и географическими условиями, Российская Федерация имеет свои особенности в становлении и развитии федеративных отношений. Про-явлением уникальности российской модели федеративного устройства явля-ется то, что в его основе сочетаются два принципа - национальный и терри-ториальный. Основой статьи являются общенаучные методы исследования, а также исторический, сравнительно-правовой, политологический, институциональный методы. Большое значение для раскрытия темы имел системный подход, при котором субъекты Федерации рассматривались как элементы целостной, сложно организованной системы федеративного государства. Системный подход позволяет показать генезис, правовой статус и проблемы становления и развития субъектов Российской Федерации как результат изменяющейся системы общественных отношений в целом, борьбы различных тенденций и политических сил в российском обществе. В работе проводится правоведческий анализ, и рассматриваются, прежде всего, инсти-туциональные и правовые аспекты совершенствования государственного устройства через призму конституционноправового статуса субъектов Рос-сийской Федерации. До подписания Федеративного договора в 1992 году, федерация строи-лась по национальному принципу, после его заключения этот принцип был дополнен территориальным. Территории, ранее являвшиеся административ-но-территориальными образованиями (края, области, города Москва и Санкт-Петербург), получили статус субъектов Российской Федерации. Сегодня в результате всех преобразований Российская Федерация состоит из более чем из 80 субъектов. Такого количества субъектов не знала прежде ни одна феде-рация в мире. Многочисленность и разнотипность этих субъектов вносит оп-ределенные трудности в систему государственного управления и формирова-ния федеративных отношений.
\end{abstract}

Ключевые слова: федерация, федерализм, субъект, Россия, компетенция, управление, разграничение, полномочие, статус, автономия.

И стория развития федерализма в России обусловлена целым комплексом присущих ей своеобразных особенностей, связанных с историческими, экономическими, социально-культурными и национально-этническими факторами. Как справедливо заметил Д.В. Доленко: «Поскольку федеративное устройство России есть воплощение принципов так называемого социалистического, советского федерализма, воплотившегося в феде- ральных устройствах и СССР и РСФСР, постольку анализ сущности российского федерализма невозможен в отрыве от анализа советского федерализма в целом» ${ }^{1}$. И, хотя Н.М. Коркунов утверждал, что «Россия могла быть только единым государством. Она никогда не образовывала и не образует ни фе-

1 Доленко Д.В. Территориальное устройство общества: социально-политический анализ. Саранск, 1993. С. 62. 
дерации, ни унии» ${ }^{2}$, все же переход к федерализму был неизбежен.

События 1917 г. с полной очевидностью показали несоответствие реалиям XX века государственного устройства Российской империи.

Отречение Николая II в пользу великого князя Михаила Александровича, противоречившее российскому законодательству и Февральская революция привели к крушению великой империи и распаду российской государственности, складывающейся веками.

После Февральской революции в империи явственно прослеживаются дезинтеграционные тенденции. В какой-то мере они поддерживались Временным правительством. У Временного правительства была идея по укреплению административных субъектов России. Независимо от этической принадлежности населения, а лишь из соображений их экологической устойчивости, предполагалась создать порядка 20 областей.

С широким разбросом программных положений по вопросу будущего государственного устройства к событиям февраля-октября 1917 года пришли российские социал-демократы. По вопросу федерализма их компетенции во многом обусловливались эволюцией взглядов на эту проблему идейных предшественников - западных социалдемократов.

Против федеративного устройства России выступила партия «Народной свободы», так как кадеты считали, что может привести к образованию слабой конфедерации или даже к распаду страны.

В проведении принципа федерации народов наиболее последовательными были эсеры. Программа партии социалистов-революционеров отличалась большей совершенностью в своих притязаниях. Первоначально эсеры вопросу государственного устройства уделяли незначительное внимание и ограничивались общими рассуждениями о праве нации на самоопределение и федерацию. Но резолюция II съезда этой партии, проходившего в мае-июне 1917 года, четко и ясно охарактеризовала состояние национальных отношений в России. Их программа была достаточно гибкой и предполагала всем народам разную форму решения вопроса: национально-культурную автономию, областную автономию, федерацию. В резолюции было записано: «...III съезд социалистов-революционеров высказывается в принципе для России за

2 Коркунов Н.М. Русское государственное право. СПб., 1914. T. 1. C. 179. федеративную форму демократической республики с территориально-национальной автономией в пределах этнографического расселения народностей с обеспечением основными законами страны как национальных меньшинств в местностях со смешанным населением, так и вообще публичных прав для всех языков, на которых говорят трудящиеся массы в России ${ }^{3}$.Обличая государственный централизм социал-демократов, лидер партии В.М. Чернов прямо апеллировал к интернационализму Бакунина, «выразившего вековую, заветную идею нашего социализма - идею федеративного переустройства исторически сложившихся государствлевиафанов внутри, идею федерирования между собою нынешних государств вовне, идею федеративной общечеловеческой кооперации равноправных народностей, автономному культурному развитию которых должны быть, обеспечены гибкие и свободные политические формы». Противники «заветной идеи нашего социализма, по Чернову, попадали в избитую, торную колею тех самых рассуждений, которые, в своей наиболее логически последовательной форме представляют типически - империалистическую аргументацию» ${ }^{4}$.

Позиция партии меньшевиков (РСДРП - меньшевики) имела общее с эсерами лишь в части познания территориальной и культурной автономии. Согласно их мнению лучшим условием единства России является отказ от федерации и «широкая политическая автономия для областей, отличающихся как национальными и этнографическими, так и культурно-историческими и социально-экономическими особенностями, а также гарантия культурного развития национальных меньшинств» ${ }^{5}$.

В марте 1917 году был издан «Акт об утверждении Конституции Великого княжества Финляндии», в это же время было признано право поляков на создание независимого государства. В июне Временное правительство признало украинскую Центральную раду и ее генеральный секретариат как официальное представительство украинской нации. Это означало, что впервые в своей истории центральное российское правительство признало национальный принцип как основу администра-

\footnotetext{
Почему СССР не отпраздновал своего 70-летия. (Несостоявшийся юбилей). М., 1992. С. 55.

4 Чернов В.М. Марксизм и славянство (К вопросу о внешней политике социализма). Пг., 1917. С. 97.

5 Почему СССР не отпраздновал своего 70-летия. (Несостоявшийся юбилей). С. 52.
} 
тивного устройства страны и передало часть своей власти национальному образованию.

Первого сентября правительство А.Ф. Керенского объявило государственный порядок в России республиканским и провозгласило Российскую республику. «Вряд ли можно сомневаться в том, что республиканский выбор России был в условиях 1917 г. безальтернативен, Керенский, подчинившись «требованиям момента», лишь зафиксировал неизбежное. Поэтому республика, несмотря на незаконность своего происхождения, имела шанс стать реальностью, обрести подлинное воплощение и даже начала его обретать, когда этот процесс был прерван октябрьским переворотом» ${ }^{6}$.

Когда произошел октябрьский переворот, перед большевиками встала труднейшая проблема: как наследники русской революции, они, прежде всего, были связаны лозунгом «Россия-агломерат накраденных провинций», в то же время им пришлось работать в среде, которая также была пропитана сходными настроениями и стремилась к разложению России, одновременно с этим большевики стали всероссийским правительством, которое стихийно не могло не принять точки зрения централизационной. Большевики, как на это было не раз указано, по программе своей вовсе небыли сторонниками децентрализации и автономии. Позиция классовой диктатуры толкала их, скорее, к централизму.

Руководители большевистской партии вплоть до октября 1917 года не ставили перед собой цели федерализации России.

В.И. Ленин видел в федерализации и децентрализации реальное замедление темпов капиталистического развития, которое может отрицательно сказаться на перспективе рабочего движения и созревания условий для социалистической революции. Он и его единомышленники проявили осторожность в определении своей позиции.

Большевики до 1917 г., отстаивая право наций на самоопределение, указывали, что пока и поскольку разные нации составляют единое государство, целесообразен не федерализм, а демократический унитаризм.

В период от февраля до октября 1917г. Российская империя распалась. Разрушилось многовековое государственное единство России.

Российская Советская Республика в октябре 1917 г. была провозглашена как унитарное госу-

6Каспэ С.И. Конструировать Федерацию RENOVATIOIMPERII как метод социальной инженерии // Полис. 2000. №5. С. 56. дарство в границах дореволюционной, царской России. Однако многонациональность России и провозглашение советской властью права наций на самоопределение активизировали тенденции к ее распаду, возникшую еще до Октября, когда народы, разбуженные Февральской революцией 1917 года, усилили национально-освободительное движение. Появились буржуазно-националистические правительства. В Сибири возникла - Областная Дума, в Закавказье и Прибалтике - национальные советы, на Украине - Центральная Рада и Генеральный Секретариат, в Оренбурге, на Тереке, Дону - казачьи Круги, на Кубани - Краевая Рада.

Ответом на новые условия стало признание и развитие большевиками идей федерализма как наиболее адекватных и эффективных. «Отрицая сначала федерализм как принцип государственного устройства, якобы способствующий разъединению наций, большевики в ходе революции вынуждены были перейти к его отстаиванию, пропагандировать этот принцип как единственную возможность склеить разбитое на куски государство» 7.

В январе 1918 г. III Всероссийский съезд Советов рабочих, солдатских и крестьянских депутатов провозгласил Россию федерацией, записав в Декларации прав трудящихся и эксплуатируемого народа, что «Советская Российская Республика учреждается на основе свободного союза свободных наций как федерация советских национальных республик». На этом съезде была принята резолюция «0 федеральных учреждениях Российской Республики». В резолюции съезда подчеркивалось, что способ участия советских республик, отдельных областей в федеральном правительстве, областей, отличающихся особым бытом и национальным составом, равно как разграничение сферы деятельности федеральных и областных учреждений Российской Республики, определяется немедленно пообразованииобластных советских республик Всероссийским Центральным Исполнительным Комитетом и Центральными Исполнительными Комитетами этих республик. Тем самым было положено начало демократического подхода к формированию федерации в России и разграничению полномочий Центра и отдельных регионов, составляющих федерацию.

Весной 1918 г. началась работа над Конституцией Российской Советской Федеративной Социалистической Республики (РСФСР).

Федеративный договор: Документы. Комментарий. М., 1992. C. 4. 
Необходимо отметить, что в момент провозглашения России федерацией национальных республик, последних еще не существовало. Первые республики, возникшие по инициативе «снизу»еще до принятия Конституции 1918 г., возникли не на национальной, а на территориальной основе. Это были Донская, Туркестанская, Кубанско-Черноморская и др., которые в ходе Гражданской войны прекратили свое существование. Восстановлены они не были, за исключением Туркестанской республики.

При определении основ советской федерации конституционная комиссия ВЦИК рассматривала два проекта - М.А. Рейснера и И.В. Сталина.

М.А. Рейснер предлагал образовать субъекты федерации без учета национального фактора, что шло в разрез с провозглашенной национальной политикой. Считая, что национальная государственность дает преимущество лицам коренной национальности, он отвергал национально - территориальный принцип формирования Российской Федерации. Рейснер предлагал в качестве основы советской федерации создавать коммуны, понимаемые как социально - экономические союзы. Провинция представлялась ему как федерация коммун, Российская Республика как федерация областей. Его план не получил поддержки.

Проект Сталина превращал Россию в федерацию советских национальных республик. Субъекты Российской Федерации по проекту Сталина это территории, с особым бытом и национальным составом населения.

На V Всероссийском съезде советов состоявшимся в июле 1918 г. первая советская Конституция была принята. В основу федеративного устройства был заложен национально - государственный принцип. Наибольшее значение имела статья 11, определявшая, что Советы областей, отличающихся особым бытом и национальным составом, могут объединиться в автономные областные союзы, которые, в свою очередь, входят на началах федерации в РСФСР.

РСФСР должна была стать федеративным государством с автономными образованиями. Однако российские автономии не могли быть созданы чисто по национальному признаку, так как население страны, подавляющее большинство которого составляли русские, было смешанным и ясных границ национального расселения не существовало. Российские автономии в угоду большевистской идеологии стали создаваться произвольно.

В первой половине 1918 г. основной и единственной формой автономии была автономная республика. Но уже во второй половине 1918 г. создается трудовая коммуна как новая форма автономии, а затем с 1920 г. применяется еще одна форма автономии - автономная область. Если учесть тот факт, что разграничение компетенции между центральным правительством и автономией не проводилось, как и не предусматривалось различий между разными формами автономии, следовательно, Россия виделась большевикам отнюдь не как федеративное государство. Ведь в федеративном государстве необходимо делится властью с регионами, что для большевиков являлось неприемлемым.

Вообще в первой российской Конституции федерализм как политическое и юридическое понятие не нес никакой государствообразующей нагрузки. Федерализм фигурировал в названии государства, в начальных главах в качестве принципа, но отсутствовал в основной части документа. Логика создателей первой российской Конституции становится вполне понятной, если принять во внимание общее мнение о временном характере Советского государства, как звене в цепной реакции мировой революции, которая должна привести сначала к всемирной федерации социалистических республик, а затем к отмиранию государства.

В национально-государственном строительстве шло два процесса: первый - это создание автономных образований внутри РСФСР, второй - создание независимых государственных образований - бывших территорий Российских империй, которые советская власть признавала, исходя из провозглашенного ею принципа самоопределения.

В конце 1918 года была образована Трудовая коммуна Немцев Поволжья впоследствии ставшая автономной республикой (1924). В 1919 году образовалась Башкирская АССР, в 1920-21 годах Киргизская (Казахская) АССР, Дагестанская, Татарская, Горская автономная республика, Карельская Трудовая коммуна, Марийская, Чувашская, Калмыцкая, Вотская (Удмуртская), автономные области. В 1921-22 годах в составе РСФСР создаются Якутская АССР, Коми, Кабардино-Балкарская, Карачаево-Черкесская, Монголо-Бурятская и другие автономные области.

Российская Федерация признала полную государственную самостоятельность Эстонии, Латвии, Литвы, Белоруссии, Украины. Затем образовываются Азербайджанская и Армянская советские республики, позже Грузинская советская республика. Вновь образовавшиеся национальные республики группировались вокруг РСФСР как федерального округа. При этом они использовали ее государственные и правовые модели. 
С 1920 года начала развиваться система двусторонних межреспубликанских договоров. Их основу составляло соглашение о тесном военном и финансово-экономическом союзе республик. Полномочный орган РСФСР, ведавший определенной областью экономики и финансов, назначал своего представителя с правом решающего голоса в республиканской СНК. Другим вариантом объединения было создание объединенных комиссариатов двух республик, эти комиссариаты входили в состав СНК РСФСР, а в составе республиканского правительства имеют своих уполномоченных. Соответственно республика посылала своих уполномоченных представителей во ВЦИК РСФСР.

И.А. Исаев пишет, что: «В период с 1918 по 1921 г. на территории бывшей Российской Империи сложилась конфедерация республик единого советского типа. Отсутствие единых для всех республик органов власти и управления заменялось делегированием их функций органами РСФСР. Основой конфедерации стал военно-политический, (а позже хозяйственно-политический) союз республик» ${ }^{8}$.

В 1921-1922 г. были ликвидированы таможенные границы между республиками, и торговое пространство стало рассматриваться как внутригосударственное и единое. На общих принципах строилось налоговое законодательство. Республики осуществляли финансирование многих хозяйственных проектов. Бюджеты республик формировались в рамках общего бюджета. Законодательство РСФСР с согласия республик действовало на их территориях.

В марте 1922 года в Тифлисе был образован Высший экономический Совет республик Закавказья, ведающий финансами, внешними связями, вопросами общей обороны, управлением экономикой и транспортом трех республик: Грузии, Азербайджана и Армении. Высшим органом сложившегося Федеративного Союза Социалистических Советских Республик Закавказья (ФСССРЗ) являлась Конференция центральных исполнительных комитетов республик. В декабре 1922 года этот союз был преобразован в Закавказскую Советскую Федеративную Социалистическую Республику (ЗСФСР) при сохранении самостоятельности входивших в нее республик. Высшим органом власти стали Съезд Советов и ЦИК. Возникла новая, по сравнению с РСФСР форма федерации, в которой составляющие ее союзные республики облада-

\footnotetext{
8 Исаев И.А. История государства и права России. М., 1996.
} C. 384 . ли более широкими правами, чем автономные в РСФСР (в области конституционного строительства, вопросах гражданства и т.п.).

Встала необходимость создания единого федеративного государства.

При обсуждении этой проблемы Сталиным была предложена концепция «автономизации». В соответствии с его идеями Украинская, Белорусская, Армянская, Грузинская и Азербайджанская советские республики должны были войти в состав РСФСР на правах автономных республик, но не как равноправные суверенные республики в составе Союза ССР. Для центральных учреждений комиссариатов республик решения высших органов государственной власти обновленной РСФСР и наиболее важных ее комиссариатов становились обязательными.

Против проекта «автономизации» выступил руководитель украинских коммунистов Х.Г. Раковский, утверждая, что проект игнорирует федеративный характер государства. Необходимо отразить особенности федеративной формы государственного устройства, которая должным образом гарантировала права республик как субъектов федерации.

И хотя Ленин расценивал сталинскую концепцию как выражение «великорусского шовинизма», однако расхождение во взглядах не носили принципиального характера. Оба они были сторонниками искусственного создания единой коммунистической нации с единым языком и культурой и стремились к денационализации наций и этносов.

30 декабря 1922 года на Первом Всесоюзном Съезде советов были приняты Договор и Декларация об образовании СССР в составе РСФСР, УССР, БССР, ЗСФСР.

«Политико-юридическая природа Союза и Российской Федерации была различной. СССР, как федерация, имел договорную природу, закрепленную затем конституционно, другими словами, СССР юридически был создан в результате договора, соглашения независимых государств. Природа Российской Федерации была иной: не ранее независимые государства создали федерацию, а само государство, провозгласившее себя федеративным, предоставило автономную национальную государственность народам, проживающим на ее территории»9.

В Декларации об образовании СССР отмечалось, что вхождение в него доступно «всем социалистическим советским республикам, как суще-

\footnotetext{
9 Доленко Д.В. Территориальное устройство общества: социально-политический анализ. Саранск, 1993. С. 64.
} 
ствующим, так и имеющим возникнуть в будущем, ... новое союзное государство явится достойным увенчанием заложенных еще в октябре 1917 года основ мирного сожительства и братского сотрудничества народов... Оно послужит верным оплотом против мирового капитализма и новым решительным шагом по пути объединения трудящихся всех стран в мировую социалистическую Советскую Республику» ${ }^{10}$. Декларация указывала на главные причины, «которые повелительно требуют объединения советских республик в одно союзное государство». Во-первых, восстановление народного хозяйства невозможно при раздельном существовании республик; во-вторых, «неустойчивость международного положения и опасность к нападению», что делает «неизбежным создание единого фронта советских республик перед лицом капиталистического окружения»; в-третьих, «само строение Советской власти, интернациональный по своей классовой природе, толкает трудящиеся массы Советских Республик на путь объединения в одну социалистическую семью». Только при этом условии можно «обеспечить и внешнюю безопасность, и внутренние хозяйственные преуспеяния, и свободу национального развития народов» ${ }^{11}$.

Обращаясь же к содержанию Договора об образовании СССР, О.И. Чистяков замечает что «договор предусматривал специфический порядок его дополнения и изменения. П. 25 гласил: «утверждение, изменение и дополнение Союзного Договора подлежит исключительному ведению Съезда Советов Союза Советских Социалистических Республик». Следовательно, республики, подписавшие Договор не вправе даже ставить вопрос об изменении и дополнении Договора; т.е. они, конечно, могут это делать, но не как участники договора, а через своих делегатов на Съезде Советов, в порядке не договорной, а законодательной инициативы. ...Договор вообще не предусматривает самой возможности денонсации, отмены его. Тем более об этом не могли ставить вопрос республики. По смыслу документа отменить его мог, очевидно, только тот орган, который его окончательно принял, а именно Съезд Советов. И далее продолжает: «Отмеченное положение, конечно, не означает, что Союз ССР становится ловушкой для его членов: вступил - значит, не можешь выйти. Как раз, наоборот, в последнем пункте договор определял право

10 Конституция общенародного государства. М., 1978. C. 213.

11 Там же. С. 213. выхода из союза каждой союзной республики, право свободного выхода, но сделать это, очевидно, могла каждая республика в отдельности, а не все сразу. При этом выход, скажем, даже двух любых республик, в том числе крупнейших, с точки зрения Договора, не мог прекратить существование Союза, две оставшиеся все равно обеспечивали существование союзного государства» ${ }^{12}$.

Таким образом, федеративные отношения в РСФСР, а затем и в СССР имели под собой два уникальных механизма. Первый - всевластие коммунистической партии. Второй - система земельных «залогов». Отказываясь от губерний, большевики подменили национально-территориального устройство государства. Автономии как бы закладывали часть своих территорий друг другу, доказывая свою приверженность идеи Советского пролетарского государства. Аналогичный подход был использован и на втором уровне федерирования Союза Советских Социалистических Республик. Россия как бы закладывала часть своих территорий тому сообществу, которое окружало Российскую Федерацию. Есть земли на Украине и в Белоруссии, которые были отданы в залог единого и военного государства.

29 января 1924 года II Всероссийский Съезд Советов принял постановление «О принятии Основного закона (Конституции) Союза Советских Социалистических Республик».

Конституция Союза Советских Социалистических Республик состояла из двух разделов: Декларации об образовании СССР и Договора об образовании СССР.

Преамбула Конституции четко отвечает на вопрос, что такое СССР. Это оказывается "мировые пролетарские Соединенные Штаты”. Создание СССР рассматривалось новым решительным шагом на пути объединения трудящихся всех стран в мировую социалистическую Советскую республику. То есть Ленину и его соратникам по коммунистической партии Россия виделась не как национальное государство и не как предельная цель их политической деятельности, но лишь в качестве плацдарма для всемирной пролетарской революции. Стратегической целью коммунистов было создание Мировой социалистической республики.

Конституция СССР, формально узаконившая союз на принципах федерализма равноправных

12 Чистяков О.И. Договор об образовании СССР и современность // Вестн. москв. ун-та. Сер. 11, Право. 1995. №2. C. $16-17$. 
и суверенных республик, гарантировала их право на отделение от СССР. Хотя в Договоре не слова не говорится о суверенитете Союза либо республик, в Конституции же, в самом начале, в ст.3 подчеркивается суверенитет союзных республик. Затем следует специальная глава, которая имеет название «о суверенных правах суверенных республик...». Итак, Конституция СССР провозглашала союзные республики суверенными государствами, имеющими свою территорию, свое гражданство, свои государственные органы и свою правовую систему. СССР, таким образом, стал с формальной точки зрения исключением среди федеративных государств. Субъекты ни одной федерации не имеют статуса суверенного государства.

Ст.1 Конституции определяет компетенцию Союза и отграничивает ее от компетенции республик. К предметам союзного ведения были отнесены: международные представительства, оборона, пересмотр границ, внешняя торговля, планирование, транспорт, связь, бюджет, деньги, кредит, государственная безопасность.

Высшим органом власти СССР объявлялся Съезд Советов СССР, избиравшийся от городских Советов и от губернских съездов Советов. В период между съездами высшим органом власти был Центральный Исполнительный Комитет СССР (ЦИК СССР). ЦИК состоял из двух законодательных палат: Союзного Совета, который избирался съездом из представителей республик пропорционально их населению, и Совета Национальностей (по 5 от автономных или союзных республик и по одному из каждой автономной области). ЦИК работал в сессионном порядке, число председателей цИК соответствовало числу союзных республик. Следовательно, Союзной Конституцией устанавливается нечто вроде двухпалатной системы. Одна из палат выражает общегосударственный принцип, другая - федеральный принцип.

Как отмечает Н.Алексеев: «Согласно Конституции СССР, Союзной ЦИК в лице двух его палат рассматривает и издает кодексы, декреты, постановления и распоряжения и объединяет работу по законодательству и управлению. Ему, следовательно, присваиваются и законодательные и правительственные функции, причем Конституция особо подчеркивает, что все декреты и постановления, определяющие общие нормы политической и экономической жизни союза, а также вносящие коренные изменения в существующую практику его органов обязательно должны поступать на рассмотрение и утверждение комитета. Постанов- ление, исходящее отЦИК имеют характер актов, обязательных на территории всего Союза. Таким образом, на всю территорию Союза простираются и широкие контрольные права комитета, который может приостанавливать или отменять декреты, постановления и распоряжения всех органов Союза, за исключением только постановлений Всесоюзного съезда Советов.

Таким образом, строение одного из главнейших органов советского государства неоспоримо имеет природу не унитарную, а федеративную» ${ }^{13}$.

В промежутках между сессиями ЦИК СССР высшим законодательным и исполнительным органом был Президиум ЦИК СССР, избиравшийся на совместном заседании палат в количестве 27 членов, в него автоматически попадают президиумы, как Совета Союза, так и Совета Национальностей. Президиум ЦИК мог приостанавливать действие постановлений съездов Советов союзных республик и отменять постановления СНК СССР, Наркоматов СССР, ЦИК СНК союзных республик.

Можно согласится с мнением Н. Алексеева, что «Советская Конституция ввела, стало быть, в государственную структуру России некоторое совершенно новое начало - начало участия отдельных частей государства в образовании верховной государственной воли. ...Части Союза определенным образом участвуют в образовании верховной государственной воли через своих представителей, избранных в Президиум Совета Национальностей и являющихся членами Президиума ЦИК.

С учетом этих постановлений было бы несправедливым отрицать в Советском государстве наличность федеративного начала» ${ }^{14}$.

«Принятая Конституция, наряду с объяснением причин образования Союза (способность обеспечить внешнюю безопасность и внутренние хозяйственные связи, свободу национального развития народов и т. д.) определяла предметы ведения федерации и ее частей, органы власти разных уровней и их компетенцию. Разумеется, процесс национально-государственного строительства, и совершенствования федерации на этом не остановился. Он продолжался, в том числе, за счет присоединения к Союзу, и за счет перехода народа к более высоким формам государственных образований из автономных областей в автономные республики, автономных республик - в союзные, изменений

\footnotetext{
13 Алексеев Н. Советский федерализм // Общественные науки и современность. 1992. №1. С. 116.

14 Алексеев Н. Указ.соч. С. 116.
} 
в административно-территориальном устройстве (районирование)» ${ }^{15}$.

Конституция СССР 1924 года предусмотрела необходимость приведения союзными республиками своих конституций в соответствие с Конституцией СССР. Выполняя это требование, XII Bceроссийский съезд Советов утвердил измененный текст Конституции РСФСР. Согласно Конституции РСФСР в редакции 1925 г. ограничивался круг полномочий верховных органов республики. Союзным органам были переданы внешние сношения, оборона, руководство транспортом и связью. Однако Российская Федерация и в рамках Союза ССР оставалась суверенным государством, суверенитет которого был ограничен лишь вопросами, отнесенными к компетенции Союза. За РСФСР сохранялось право свободного выхода из Союза ${ }^{16}$.

Многочисленные дополнения в Конституцию РСФСР 1925 года были внесены в связи с развитием автономии. Если Конституция РСФСР 1918 года лишь в трех статьях и в общих чертах регулировала проблему автономии, то в Конституции 1925 года, ей посвящена специальная глава. Кроме того, вопросы автономии поднимались и в других статьях. Конституция РСФСР закрепляла формы автономии - автономную республику и автономную область. В ней в общих чертах определялась конструкция их государственного механизма, границы компетенции, закреплялись избирательная система, права и обязанности граждан, государственная символика. Хотя статус автономий после принятия Конституции РСФСР не изменился. Прослеживалась общая тенденция движения к фактическому унитаризму. В обществе постепенно утверждалось понимание того, что собственно национальные интересы укладываются в рамки культурной автономии каждого народа. Считалось, что субъекты федерации являются национальными по форме (хотя таковыми они по существу и не являлись), социалистическими по содержанию.

Главное звено формирующийся в СССР командно-административной системы, каким была коммунистическая партия, рассматривающаяся как сила интернациональная, превращало декларируемое федеративное государство практически в унитарное. Поэтому не случайно во второй половине 20-х - первой половине 30-х годов внимание

15 Королева-Конопляная Г.И. / Основы национальных и федеративных отношений. М., 2001. С. 279.

16 Карапетян Л.М. Федеративное устройство Российского государства. М., 2001. С. 51. к процессам государственного устройства РСФСР было существенно ослаблено. Хотя следует отметить, что ряд автономий повысили свой государственный статус - стали союзными республиками. В центр внимания правящей партии было поставлено укрепление СССР, который преподносился как шедевр ленинско-сталинской национальной политики и который стал по существу унитарным государством, становым хребтом которого была административно-командная система власти.

На основе принципа демократического централизма строились и государственный аппарат СССР и правящая партия: во-первых, органы государственной власти и государственного управления образовывали единую систему, построенную на основе строжайшего подчинения нижестоящих органов руководству и контролю вышестоящих, во-вторых, акты вышестоящих органов были обязательны для нижестоящих.

За период с 1924 до 1936 года в стране произошли существенные изменения. Многоукладная экономическая структура была реконструирована с целью усиления государственного планового сектора. Произошли значительные изменения в сфере национально-государственного строительства. Значительные перемены произошли в структуре и системе органов государственного управления и управления народным хозяйством.

В новой Конституции СССР 1936 года государственное устройство определялось как федеративное (союзное) объединение республик. Приводился перечень прав федеративных органов, не перечисленные полномочия остались за союзными республиками. Последним предоставлялось право выхода из состава СССР, конституции союзных республик должны были соответствовать Конституции СССР, в случае расхождения союзного и республиканского законов действовал союзный закон.

21 января 1937 года была принята новая Конституция РСФСР. Эта Конституция закрепила наличие в составе Федерации 17 автономных республик и 6 автономных областей, а также упомянула в связи с установлением системы местных органов государственной власти о наличии в республиках национальных округов.

Во второй половине $30-$-х годов сталинский тоталитарный режим и фактический унитаризм СССР окончательно утвердились. Поэтому в национальной политике можно было уже совершенно не учитывать декларируемый федерализм РСФСР, что нашло наглядное подтверждение в действиях центральных властей в годы Великой 
Отечественной войны по отношению к целым народам, создавшим свои автономные образования в рамках РСФСР. Автономии были ликвидированы, а сами народы (карачаевцы, калмыки, ингуши, чеченцы, немцы, балкарцы, крымские татары) депортированы. Конституционные гарантии и декларируемый федерализм не оказали, да и не могли оказать в условиях существования тоталитарного режима какого-либо сдерживающего влияния на политику репрессий. Из этого можно сделать вывод, что федерализм и тоталитаризм несовместимы.

В 1977 году принимается Конституция СССР, которая провозглашает Советский Союз единым многонациональным государством. Она закрепляла принципы демократического централизма как основу организации и деятельности Советского государства.

Глава1 «Политическая система» не оговаривала федеративный характер государства, не закрепляла принцип федерализма. Статья 9 этой главы, перечисляющая направления развития политической системы советского общества не ставила задачей совершенствование союзного государства как федерации. В статье 1 СССР трактовался как социалистическое общенародное государство, выражающее волю и интересы рабочих, крестьян и интеллигенции, трудящихся всех наций и народностей страны.

В апреле 1978 года была принята новая Конституция РСФСР, которая вновь зафиксировала суверенный статус РСФСР и ее право свободного выхода из СССР. «Такое право, - пишет В. Пустогаров, - не способствовало прочности советской федерации, и не удивительно, что для него не нашлось места в Конституции РСФСР 1993 года» ${ }^{17}$.

Конституция РСФСР 1978 года не внесла каких-либо существенных изменений в правовой статус автономных республик, автономных областей и автономных округов. Россия оставалась федерацией по форме, но не по содержанию. Утвердившиеся положения о развитии двух видов советской федерации, первым из которых было объединение суверенных государств (союзная федерация), а вторым - федерация на базе автономии (РСФСР), в сущности, уводило в сторону от главного вывода: в СССР осуществлялась политика, направленная на его превращение в унитарное государство. Поэтому Конституции РСФСР 1937

\footnotetext{
17 Пустогаров В. Своеобразие российского федерализма //
} Международная жизнь. 1995. №1. С. 82. и 1978 гг. сознательно уходили от определения круга вопросов субъектов федерации, сохраняя за центром непосредственное командование местами. От новой Конституции требовалось одно: четко определить взаимоотношения между Российской Федерацией и ее субъектами, решить проблему суверенитета, целостности и неприкосновенности территории России.

Реальная жизнь между тем активно отходить от конституционных канонов. Последовательная демократизация всех сторон жизни страны, ослабление тоталитарного режима усилили стремление союзных республик к обретению подлинной независимости. Особую актуальность приобретает дилемма дальнейшего развития советской федерации: либо повышение самостоятельности союзных республик де-факто, либо признание Союза унитарным государством де-юре.

«Нельзя утверждать, что вообще не было попытки реформировать советский федерализм. В годы так называемой перестройки вопросы реорганизации Советского союзного государства были предметом острых дискуссий в научной среде и в средствах массовой информации. В это время (конец 80-х гг.) были выдвинуты идеи организации республиканского хозрасчета, самодостаточности республиканских территориальных общностей, создания относительно обособленных экономических организмов в пределах народохозяйственного комплекса СССР, обеспечения республиканского экономического суверенитета ${ }^{18}$ ».

Значительным шагом Российской Федерации на пути перехода от тоталитарного к демократическому федерализму стала Декларация «0 государственном суверенитете Российской Советской Федеративной Социалистической Республики», принятая 12 июня 1990 года первым съездом РСФСР и провозгласившая государственный суверенитет на всей ее территории. Она отразила политические реалии ситуации, которая имела место в середине 1990 года. Провозглашение суверенитета РСФСР на всей ее территории сочеталось с заявлением о решимости создать демократическое правовое государство в составе обновленного Союза ССР.

Разрушения государственного единства можно было не допустить путем создания подлинной федерации. Но федералистское начало было формальным и поэтому не явилось фактором стаби-

18 Иванов В.Н., Яровой О.А. Российский федерализм: становление и развитие. М., 2001. С. 22. 
лизации при возникновении угрозы единству государства. Все попытки наполнить новым содержанием советский федерализм так и не увенчались успехом.

После призыва к автономиям брать власти столько, сколько они могут «проглотить», все республики Российской Федерации заявили о своем суверенитете и отказе от статуса автономий, все автономные области (кроме Еврейской) обьявили себя суверенными республиками. Все без исключения рспублики выразили желание быть участниками учредительного Союзного договора.

В период до разработки и опубликования нового Союзного договора, ученые предлагали различные способы снижения межнациональной напряженности и обновления Советского федеративного государства.

Выдвигался план дефедерализации и десоветизации и отказ от построения федерации на национальной основе, ликвидации национальных государств. Другие предлагали всем автономным образованиям предоставить статус республик как субъектов СССР или же признать их субъектами СССР в качестве автономных образований ${ }^{19}$. Было и более радикальное предложение, согласно которому на статус государств в составе СССР могут претендовать даже автономные области и округа, а также добровольные территориальные объединения, группы административно-политических образований ${ }^{20}$.

Также предлагалось оставить три группы субъектов СССР. Во-первых, сам Союз ССР как самостоятельный субъект права. Вторая группа субъектов - суверенные республики, образующие союз на принципах федерализма. Третья группа - республики не пожелавшие остаться в составе СССР, с ними можно установить конфедеративные отношения путем заключения соглашений об их особом статусе $^{21}$.

Но новый Союзный Договор не был принят. Грянули Беловежские соглашения. Стремление к самоопределению победило тенденцию к многове-

\footnotetext{
19 См.: Нерсесянц В. С. Демократизация Советского общества и государственно-производственные аспекты национальных отношений в СССР // Сов.государство и право. 1989. №1. С. 34.

20 См.: Зубов А.Б., Салмин А.М., Тайван Л. Л. Союзный Договор (авторский проект) // Нар.депутат. 1990. №6. С. 78.

21 См.: Крылов Б.С., Кузнецов И.Н., Михалева Н.А. Концепция Союзного Договора // Сов.государство и право. 1990. №10. C. 6 - 7 .
}

ковому совместному проживанию народов, и СССР в декабре 1991 г. распался.

Важной вехой на пути от унитарной государственности к федерализму нового типа стал Федеративный договор, подписанный в марте 1992 года между Российской Федерацией и ее субъектами.

Федеративный договор «О разграничении предметов ведения полномочий между федеральными органами государственной власти РФ и органами суверенных республик в составе РФ» разграничил предметы ведения Российской Федерации и предметы совместного ведения Российской Федерации и ее субъектов, указав при этом, что республики обладают всей полнотой государственной власти РФ. Договор был подписан Российской Федерацией и всеми республиками, кроме Чечни и Татарстана. Аналогичные договоры были подписаны Российской Федерацией и органами власти краев, областей, городов Москвы и Санкт-Петербурга, автономной области и автономных округов в составе Российской Федерации.

Три отдельных текста Договора как бы закладывают разнотипность будущих субъектов Федерации. По территориально-государственному признаку выделены следующие образования: 1) национально-государственные (республики); 2) национально-территориальные (автономная область, автономные округа); 3) административнотерриториальные образования (края, области, города федерального значения).

В России начался качественно новый этап развития Федерации и федеративных отношений. В рамках определенных в Договоре полномочий субъекты Российской Федерации обрели возможность осуществлять собственное государственное строительство, набираться опыта государственного состояния и законотворчества, что столь необходимо для становления подлинного федерализма. Но «...если рассматривать две основные стороны, характеризующие любое федеративное государство: систему территориально-государственного устройства и систему отношений между федеральными и региональными органами власти, то Федеративный договор изменил только систему отношений между властями и не затронул проблем административно-территориального деления (границ территорий), не учредил новых административных единиц в составе Российской Федерации» ${ }^{22}$. Однако: «...сделан шаг на пути от

22 Медведев Н.П. Политическая регионалистика: Учебник. M., 2002. C. 36. 
национально-территориальной к смешанной федерации, где субъектами являются как национально-территориальные, так и территориальные единицы. Это, несомненно, в какой-то степени отражает требования политических сил, представляющих население, преимущественно русское, краев и областей» ${ }^{23}$.

Основные положения Федеративного договора вошли в Конституцию Российской Федерации, принятой в 1993 году.

Следует отметить, что Конституция РФ и Федеративный договор имеют разное правовое значение в регулировании государственного устройства страны. «Доминирующее положение занимает Конституция РФ, которая устанавливает конституционную, а не договорно-конституционную или договорную природу Российской Федерации. Основу верховенства на всей территории России федеральной Конституции составляет не договор, а союз, в который объединяются субъекты РФ, а единство суверенной власти, которое существовало до и сохраняется после подписания Федеративного договора и не

ставится под сомнение иными договорами, заключенными федеральными органами государственной власти и органами государственной власти субъектов Федерации» ${ }^{24}$.

После принятия Конституции Российской Федерации угроза территориальной целостности и опасность распада России ослабли. Конституция РФ подчеркивает, что в основе федеративного устройства России лежит примат ее государственной целостности. В статье 4 зафиксировано, что суверенитет Российской Федерации обеспечивает целостность и неприкосновенность своей территории. «Территория Российской Федерации включает в себя территории ее субъектов внутренние воды и территориальное море, воздушное пространство над ними» (ст.67). Субъекты Федерации не вправе выходить из состава России. Тем самым поставлен правовой предел попыткам расшатать или разрушить единство Российской Федерации.

Таким образом, подводя итог сказанному можно отметить, что особенностью советской модели федерализма было то, что она рассматривалась не как модель демократизации страны, а как средства решения национального вопроса.

23 Доленко Д.В. Указ.соч. С. 73 - 74.

24 Эбзеев Б.С., Карапетян Л.М. Российский федерализм: равноправие и асимметрия конституционного статуса субъектов // Государство и право. 1995. №3. С. 9.
С начала строительства государства нового типа большевики считали классовый подход более важным, нежели этнический. Поэтому они отвергали федерацию. Но им пришлось поневоле изменить свою позицию и присоединиться на словах к той позиции, которую занимали российские социал-демократы, меньшевики и социалистыреволюционеры и провозгласить право народов на самоопределение вплоть до отделения. Изменить свои взгляды в пользу федерализма подвигло большевиков и усилившееся национальное движение. Итогом стало создание федерации этнических советских государств. Сама идея федерализма провозглашалась временно для решения национального вопроса. В условиях социализма при провозглашении и законодательном закреплении внешних атрибутов федеративного государства на практике возобладал унитаристский подход. Это объяснялось и унитаристским принципом строительства руководящей партии.

Федерализм РСФСР еще менее соответствовал своему существу. Большая часть ее территорий управлялась на унитарных началах. Закрепление в Конституции СССР неограниченной власти Центра лишало субъекты РСФСР свободы действий.

Несмотря на непоследовательность и противоречивость положений подписанного в 1992 году Федеративного договора федеративные отношения были распространены на всю территорию России: как на бывшие автономные республики и автономные образования, так и на бывшие административные территориальные единицы - края, области, города федерального значения.

Определенный шаг в развитии федеративных отношений в России был сделан с принятием Конституции 1993 года, в соответствии с которой все субъекты Российской Федерации равноправны между собой и во взаимоотношениях с федеральными органами государственной власти.

Во многом от того, удастся ли перейти к подлинно федеративному государству, зависит дальнейшая судьба России. Но, при преобразовании российского федерализма надо помнить, что у российской федеративности свои истоки, и без понимания этого, построение стабильной и прочной государственности практически невозможно. 


\section{Библиография:}

1. Доленко Д.В. Территориальное устройство общества: социально-политический анализ. Саранск, 1993.

2. Исаев И.А. История государства и права России. М., 1996.

3. Иванов В.Н., Яровой О.А. Российский федерализм: становление и развитие. М., 2001.

4. Коркунов Н.М. Русское государственное право. СПб., 1914. Т. 1.

5. Каспэ С.И. Конструировать Федерацию - RENOVATIOIMPERII как метод социальной инженерии // Полис. 2000. №5.

6. Нерсесянц В. С. Демократизация Советского общества и государст-венно-производственные аспекты национальных отношений в СССР // Со-ветское государство и право. 1989. № 1.

7. Чернов В.М. Марксизм и славянство (К вопросу о внешней политике социализма). Пг., 1917.

8. Эбзеев Б.С., Карапетян Л.М. Российский федерализм: равноправие и асимметрия конституционного статуса субъектов // Государство и право. 1995. № 3.

9. Н. М. Добрынин, М. В. Глигич-Золотарева Управление развитием федерации: прикладной системный анализ в сфере государственно- территориального устройства. Часть 4. Алгоритм решения системных проблем федерализма // Право и политика. - 2011. - 9. - С. 1414 - 1430.

10. Пирбудагова Д.Ш., Исабагандова И.И. К вопросу о компетенции законодательных (представительных) органов государственной власти субъектов Российской Федерации // Право и политика. - 2014. - 6. - С. 807 - 811. DOI: 10.7256/1811-9018.2014.6.12265.

11. М.С. Басиев К вопросу о реализации в Российской Федерации концепции «исполнительного федерализма» // Право и политика. - 2013. - 2. - C. 174 - 181. DOI: 10.7256/1811-9018.2013.02.3.

12. Иналкаева К.С. Проблемы разграничения предметов ведения между федеральным центром и субъектами // Право и политика. - 2014. - 6. - C. 746 - 753. DOI: 10.7256/1811-9018.2014.6.12244.

\section{References (transliterated):}

1. Dolenko D.V. Territorial'noe ustroistvo obshchestva: sotsial'no-politicheskii analiz. Saransk, 1993.

2. Isaev I.A. Istoriya gosudarstva i prava Rossii. M., 1996.

3. Ivanov V.N., Yarovoi O.A. Rossiiskii federalizm: stanovlenie i razvitie. M., 2001.

4. Korkunov N.M. Russkoe gosudarstvennoe pravo. SPb., 1914. T. 1.

5. Kaspe S.I. Konstruirovat' Federatsiyu - RENOVATIOIMPERII kak metod sotsial'noi inzhenerii // Polis. 2000 . №5.

6. Nersesyants V. S. Demokratizatsiya Sovetskogo obshchestva i gosudarst-venno-proizvodstvennye aspekty natsional'nykh otnoshenii v SSSR // So-vetskoe gosudarstvo i pravo. 1989. № 1.

7. Chernov V.M. Marksizm i slavyanstvo (K voprosu o vneshnei politike sotsializma). Pg., 1917.

8. Ebzeev B.S., Karapetyan L.M. Rossiiskii federalizm: ravnopravie i asimmetriya konstitutsionnogo statusa sub"ektov // Gosudarstvo i pravo. 1995. № 3.

9. N. M. Dobrynin, M.V.Gligich-Zolotareva Upravlenie razvitiem federatsii: prikladnoi sistemnyi analizv sfere gosudarstvennoterritorial'nogo ustroistva. Chast' 4. Algoritm resheniya sistemnykh problem federalizma // Pravo i politika. - 2011. 9. - C. $1414-1430$.

10. Pirbudagova D.Sh., Isabagandova I.I. K voprosu o kompetentsii zakonodatel'nykh (predstavitel'nykh) organov gosudarstvennoi vlasti sub"ektov Rossiiskoi Federatsii // Pravo i politika. - 2014. - 6. - C. 807 - 811. DOI: 10.7256/18119018.2014.6.12265.

11. M.S. Basiev K voprosu o realizatsii v Rossiiskoi Federatsii kontseptsii «ispolnitel'nogo federalizma» // Pravo i politika. 2013. - 2. - C. 174 - 181. DOI: 10.7256/1811-9018.2013.02.3.

12. Inalkaeva K.S. Problemy razgranicheniya predmetov vedeniya mezhdu federal'nym tsentrom i sub"ektami // Pravo i politika. - 2014. - 6. - C. 746 - 753. DOI: 10.7256/1811-9018.2014.6.12244. 